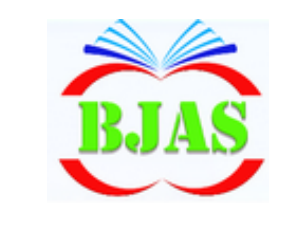

ISSN $1814-5868$

Basrah J. Agric. Sci., 32(2): 85-94, 2019

Available online at $\underline{\text { http://journal.bajas.edu.iq }}$ https://doi.org/10.37077/25200860.2019.199

College of Agriculture, University of Basrah

\title{
Effect of POU1F1 Gene Haplotypes on Eights and Milk Production of Awassi Sheep
}

\author{
Azhar A. Jaffar*, Amad F. Hassan \& Waleed Y. Kassim \\ Department of Animal Production, College of Agriculture, University of Basrah, Iraq \\ *Corresponding author Email: azhareabd5@gmail.com
}

Received 17 June 2019; Accepted 14 July 2019; Available online 31 December 2019

\begin{abstract}
The aim of the study was to detect polymorphism in the POU1F1 gene in Iraqi Awassi sheep breed, as well as to establish if haplotype of $P O U 1 F 1$ gene could be associated with productive traits. This study was carried out at Al-Kafeel station, Karbala city during the period of 01/10/2017 until 01/08/2018. The study included 46 Awassi ewes with their 52 lambs. The laboratory analyses were conducted at the Laboratory of Molecular Genetics, College of Agriculture, University of Basrah. Results showed the successfulness of the PCR amplification process for all six examined fragments of the POU1F1 gene. Gel electrophoresis was conducted using agarose $2 \%$, the product sizes were 637bp, 789bp, 999bp, 868bp, $1190 \mathrm{bp}$, and 469bp for the fragments P1, P2, P3, P4, P5, and P6 respectively. The analysis of the nitrogen bases sequences of the POU1F1 gene for the studied fragments showed a change in 12 different sites of the gene. These changes resulted in 7 haplotypes of $\mathrm{H} 1-\mathrm{H} 7$. The results showed significant influence $(\mathrm{P}<0.05)$ in haplotypes of the POU1F1 gene on birth weight. However, haplotypes showed no significant effect on lambs' weights at weaning, six months and daily weight gains during all periods. Statistical analysis showed that different haplotypes of the POU1F1 gene did not influence on milk productive traits. The examined fragments of the POUIF1 Awassi gene have been submitted to Gene Bank under the accession numbers (LC469323 to LC469349).
\end{abstract}

Keywords: Awassi sheep, Haplotypes, POU1F1 gene, Traits production.

\section{Introduction}

The Polymorphisms of genes at specific sites of the genome has become one of the important signs in the detection of animal characteristics such as productive and physiological traits. Among the genes that have multiple Polymorphisms are POU1F1, which is called Factor 1. ThePOU1F1 gene found in sheep, goats, and cattle on the chromosome (1) at the location 1q21-22 (Woollard et al., 2000).
The gene expression of the POU1F1 gene occurs mainly in pituitary gland cells and in other tissue cells as mammary gland tissues (Gil-Puig et al., 2002). The POU1F1 gene consists of six exons and five introns. The exons encode into a protein of 291 amino acids. POU1F1 gene function and composition are similar with its bovine, human and rat counterparts showing $98.2 \%$, $91.2 \%$ and $86.2 \%$ respectively (Bastos et al., 
2006). This gene is called GHF-1, a gene that regulates the gene expression of growth hormone $(\mathrm{GH})$, prolactin hormone (PRL) and thyroid stimulating hormone (TSH- $\beta$ ) (Sun et $a l$. ., 2002). The researchers found that the polymorphism of POU1F1 gene is associated with several economic characteristics such as weight at birth, weaning weight, weight gains in sheep (Sadeghi et al., 2014; Al-Khuzai, 2018) and in goats (Zhu et al., 2019).

Although there is an increasing interest in studying the polymorphism of the POU1F1 gene and its association with specific characters of different animal species in the past years, but the studies on sheep are still few, especially local sheep breeds. Therefore, this study aimed at explaining the effect of genetic polymorphism (haplotypes) of the POU1F1 gene on the performance of Iraqi Awassi sheep.

\section{Materials \& Methods}

This study was carried out at AL-Kafeel station, Karbala city during the period of 01/10/2017 until 01/06/2018. The study included 46Al-Awassi ewes and 52 lambs from their births. The laboratory analyses were conducted in the Laboratory of Molecular Genetics, College of Agriculture, University of Basrah.

Daily milk yield recording started from the fourth day after birth until the ewes drying. Every 10 days, the lambs were separated from their dams for 12 hours. Lambs weighed before and after suckling to measure the amount of milk yield. Additionally, after suckling, the ewes were hand milked soon after to get the milk left in their udders and this quantity of milk was recorded. Daily milk yield was considered as twice the morning milk yield.. Calculation of the milk components (fat, protein, and lactose) was performed each time. Milk components was estimated by the Eko-milk analyzer, the Faculty of Veterinary Medicine at Al-Qasim Green University. Lambs weights were taken at birth, weaning, and at 6 months of age using a sensitive electronic balance. Growth rates were calculated as the difference between two different periods divided by the number of days during the same period.

Blood was collected from the jugular vein of ewes and placed in $4 \mathrm{ml}$ test-tubes containing EDTA. (Ethylene diamine tetra acetic acid). DNA Extraction Kit (Genaid, Taiwan) was used to extract the DNA. The concentration and purity of the DNA were confirmed using the nanodrop device. The DNA concentration ranged between 29.3-71.9 ng/ul. The purity OD (optical density) $(260 / 280)$ was $1.6^{-}-1.92$. The DNA extraction process was confirmed by gel electrophoresis using $1 \%$ agarose and the Diamond TM Nucleic Acid Dye (produced by Promega, USA). Six fragments of the POU1F1 gene were selected, including all six exons as well as parts of the introns. Primers of these fragments (P1-P5) were designed based on the reference copies recorded under the accession numbers (AJ549205, AJ549204, AJ549206, and AJ549207) at the Gene Bank (NCBI). The fragment (P6) was adopted by Ozmen, et al. (2014). Table (1) showed the sequences of the used primers, fragments sizes, and annealing temperature. Primers were manufactured by Bromega Company, USA. PCR product was $25 \mu \mathrm{l}$, containing 12.5 $\mu 1$ Master Mix, $1 \mu 1$ for each primer forward \& reverse, $3 \mu$ DNA template and dd water were added to $25 \mu 1$. The amplification successfulness was confirmed by migrated PCR products by electrophoresis using $2 \%$ 
agarose and the Diamond TM Nucleic Acid Dye produced by Promega USA. Twenty microliters of PCR products were sent to Yang Ling Biotechnology Co; Ltd. China to analyze the sequencing of the nitrogen bases of the POU1F1 gene for the studied fragments of all samples.

The results of the nitrogen bases sequencing of the six studied fragments of the POU1F1 gene were analyzed by using Bio edit V.7.2.6 software to align the sequences of the fragments, DnaSP V. 6.12 was used to calculate haplotypes and haplotypes frequencies. The haplotypes network for the POU1F1 gene was constructed using Network V. 5.5 program
The statistical program SPSS (2013) v.23 was used to find the significant differences between the means of the studied traits and the age of dams, sex lambs and birth type were adjusted by Statistical model:

Yijklm $=\mu+\mathrm{Ai}+\mathrm{Sj}+\mathrm{Mk}+\mathrm{Gl}+$ eijklm Where is:

$\mu=$ Overall mean

Yijklm = The value of observation of each trait.

$\mathrm{Ai}=$ Effect age of dams $(\mathrm{i}=3)$.

$\mathrm{Sj}=$ Effect sex of Lamb $(\mathrm{j}=2)$.

$\mathrm{Gm}=$ Effect type of birth $(\mathrm{m}=2)$

Table (1): Primers of POU1F1 gene, their sizes and annealing degrees.

\begin{tabular}{llcc}
\hline Fragment & \multicolumn{1}{c}{ Primers } & $\begin{array}{c}\text { Annealing } \\
\text { Temperature }\end{array}$ & $\begin{array}{c}\text { Product } \\
\text { Size }\end{array}$ \\
\hline P1 & F: 5'- AGTGAGATCT GAAACGGCCC - 3' & 55 & $637 \mathrm{bp}$ \\
& R: 5'- ACTATGAGGT GTACGGCATTT - 3' & & \\
\hline P2 & F: 5' - AAAACTGGTCAGTCACGCCA- 3' & 60 & $868 \mathrm{bp}$ \\
& R: 5' - GTATGGAGGCGG GCAATGAA - 3' & & \\
\hline P3 & F: 5' - TTCCCAGCAGAGCACTTAACA -3' & 58 & $780 \mathrm{bp}$ \\
& R: 5' - GTGC TTGTTAACAGCTGTGGGA - 3 & & \\
\hline P4 & F: 5' - ACCAGGCAATTCTA CACTGAG - 3' & 55 & $1190 \mathrm{bp}$ \\
& R: 5' -TCTCAATTGGCTCTA TTCATTTTCA -3' & & \\
\hline P5 & F: 5'- TCCCTCGGTTGAA TTTGTGCTA -3' & 58 & $999 \mathrm{bp}$ \\
& R: 5'- TCCA AAGCCTGCAGAGCAAA -3' & & \\
\hline P6* & F: 5'- GTATTGCTGCTAAAG ACGCC -3' & 54 & $469 \mathrm{bp}$ \\
& R: 5'- GAGG GAAAGATATAGTGAAAGGG -3' & & \\
\hline
\end{tabular}

$\mathrm{Gl}=$ Effect haplotype of POU1F1 gene (l=7)eijmk = The effect of the experimental error which is distributed randomly and naturally and with an average of zero and variation. $\sigma^{2} \mathrm{e}$.

\section{Results \& Discussion}

\section{Amplification and Sequencing of the POU1F1 gene}

Results showed the successfulness of the PCR amplification process for all six examined fragments of the POU1F1 gene. The products sizes were 637bp, 868bp, 789bp, 1190bp, 999bp and 469bp for fragments P1, P2, P3,
P4, P5, and P6, (Fig.1). A total of 12 nucleotides polymorphisms (Fig. 3). These changes resulted in 7 haplotypes $(\mathrm{H} 1, \mathrm{H} 2, \mathrm{H} 3$, $\mathrm{H} 4, \mathrm{H} 5, \mathrm{H} 6$, and $\mathrm{H} 7$ ), with frequencies of $0.478,0.282,0.108,0.065,0.022,0.022$ and 0.022 , respectively (Table 2 ). 


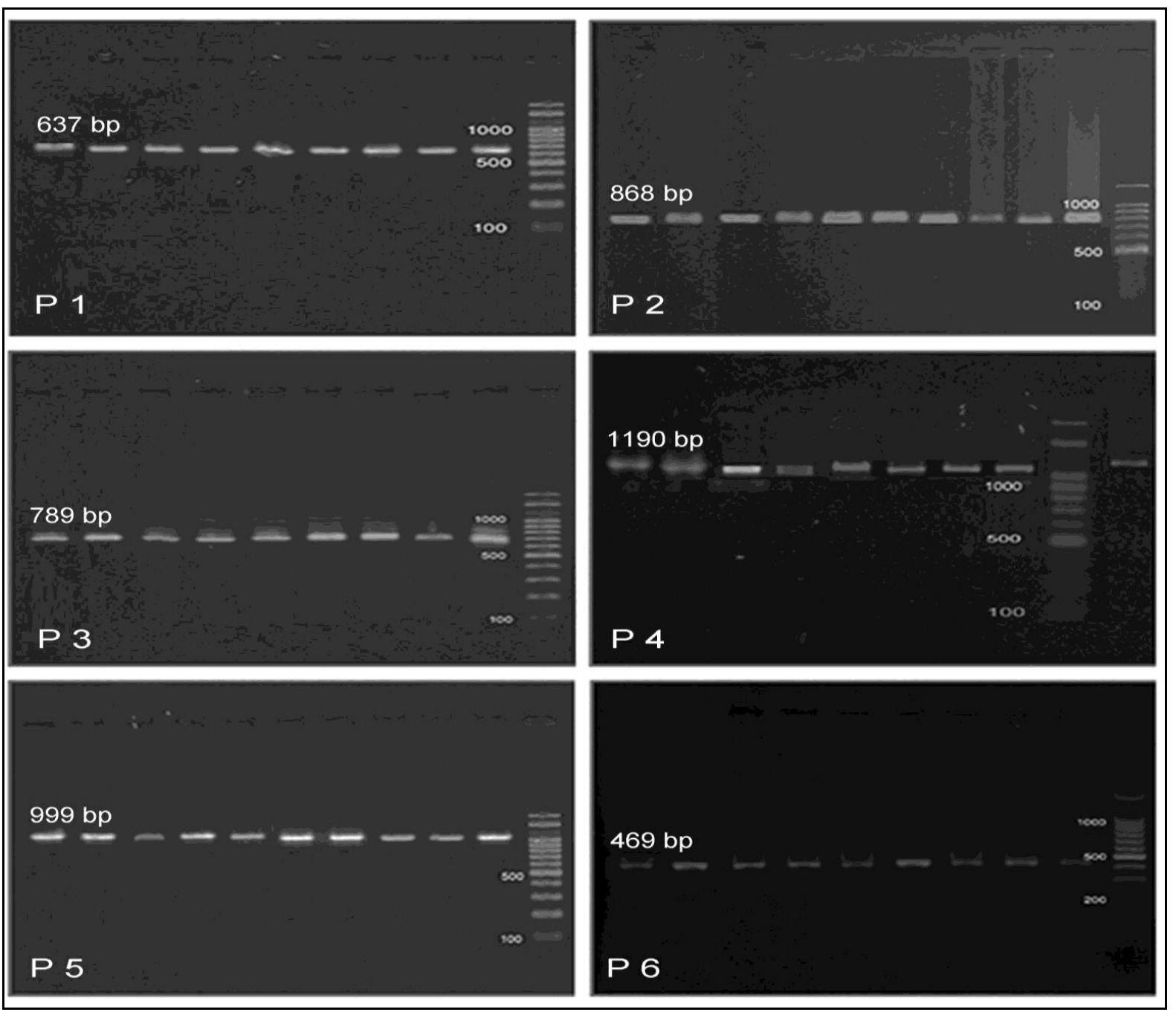

Fig. (1): The amplification results of the examined Fragments of POU1F1 gene.

Table (2): Haplotypes of the POU1F1 gene.

\begin{tabular}{cccc}
\hline No. & $\begin{array}{c}\text { No. of } \\
\text { Animals }\end{array}$ & $\begin{array}{c}\text { Frequency of } \\
\text { haplotype }\end{array}$ & Haplotypes \\
\hline H1 & 22 & 0.478 & CGGCAAGAGTAA \\
\hline H2 & 13 & 0.282 & CGGCACGAATAG \\
\hline H3 & 5 & 0.108 & CGGCCAGAATAG \\
\hline H4 & 3 & 0.065 & CGGCCAAGGTAA \\
\hline H5 & 1 & 0.022 & CGGCAAGAAGAA \\
\hline H6 & 1 & 0.022 & CGGCACGAGGTG \\
\hline H7 & 1 & 0.022 & TACGAAGAGTAA \\
\hline Total & 46 & 1 & \\
\hline
\end{tabular}




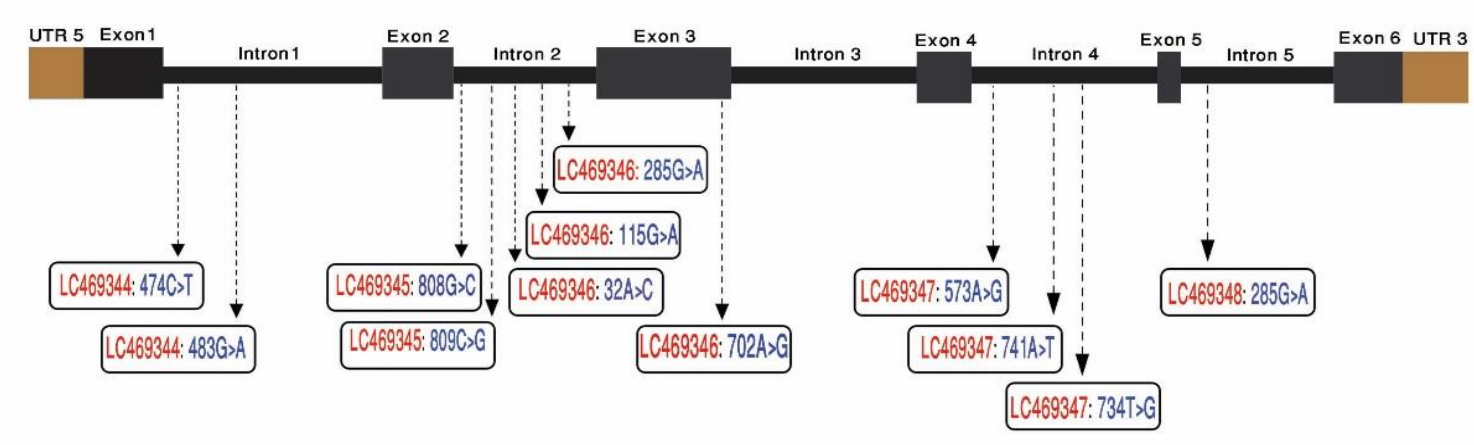

Fig. (3): Changes obtained from analyzing sequences of six different fragments of the gene.

\section{Effect of haplotypes on total and daily weight gain}

Table (3) showed the influence of the haplotypes of the POU1F1 gene on the weight from birth into six month of age and daily weight gains of the lambs. The results showed that birth weight of the haplotype $\mathrm{H} 3$ and $\mathrm{H} 4(4.20$ and $4.33 \mathrm{~kg})$ were significantly higher $(\mathrm{P}<0.05)$ compared to $(3.67,3.70$ and $3.50 \mathrm{~kg}$ ) for haplotypes $\mathrm{H} 1, \mathrm{H} 2$ and other respectively.

Table (3): Effect of haplotypes of POU1F1 gene on weights \& average daily gain \pm standard deviation.

\begin{tabular}{|c|c|c|c|c|c|c|c|}
\hline Haplotypes & $\begin{array}{l}\text { Nom. } \\
\text { of } \\
\text { animals }\end{array}$ & $\begin{array}{l}\text { Birth } \\
\text { weight } \\
(\mathrm{kg})\end{array}$ & $\begin{array}{l}\text { Weaning } \\
\text { weight } \\
(\mathrm{kg})\end{array}$ & $\begin{array}{l}\text { Six months } \\
\text { weight } \\
\text { (kg) }\end{array}$ & $\begin{array}{l}\text { average daily } \\
\text { gain from } \\
\text { birth weaning } \\
(\mathrm{kg} / \mathrm{d})\end{array}$ & $\begin{array}{l}\text { average } \\
\text { daily gain } \\
\text { from } \\
\text { weaning to } \\
\text { six months } \\
(\mathrm{kg} / \mathrm{d})\end{array}$ & $\begin{array}{l}\text { average } \\
\text { daily gain } \\
\text { from birth } \\
\text { to six } \\
\text { months } \\
(\mathrm{kg} / \mathrm{d})\end{array}$ \\
\hline H1 & 22 & $\begin{array}{l}3.67 \pm \\
0.73 \mathrm{~b}\end{array}$ & $\begin{array}{c}15.46 \pm \\
1.44\end{array}$ & $\begin{array}{c}27.31 \pm \\
2.07\end{array}$ & $\begin{array}{c}0.132 \pm \\
0.014\end{array}$ & $\begin{array}{c}0.129 \pm \\
0.016\end{array}$ & $\begin{array}{c}0.131 \pm \\
0.01\end{array}$ \\
\hline $\mathrm{H} 2$ & 12 & $\begin{array}{r}0.74 \pm \\
3.70 \mathrm{~b}\end{array}$ & $\begin{array}{c}15.48 \pm \\
1.33\end{array}$ & $\begin{array}{c}27.14 \pm \\
2.05\end{array}$ & $\begin{array}{c}0.130 \pm \\
0.009\end{array}$ & $\begin{array}{c}0.129 \pm \\
0.017\end{array}$ & $\begin{array}{c}0.130 \pm \\
0.009\end{array}$ \\
\hline H3 & 5 & $\begin{array}{c}4.20 \pm \\
0.53 \mathrm{a}\end{array}$ & $\begin{array}{c}15.84 \pm \\
2.34\end{array}$ & $\begin{array}{c}28.16 \pm \\
2.55\end{array}$ & $\begin{array}{c} \pm 0.132 \\
0.021\end{array}$ & $\begin{array}{c}0.133 \pm \\
0.016\end{array}$ & $\begin{array}{c}0.133{ }^{ \pm} \\
0.011\end{array}$ \\
\hline $\mathrm{H} 4$ & 3 & $\begin{array}{c}4.33 \pm \\
0.57 \mathrm{a}\end{array}$ & $\begin{array}{c}15.93 \pm \\
0.50\end{array}$ & $\begin{array}{c}29.27 \pm \\
1.62\end{array}$ & $\begin{array}{c}0.136 \pm \\
0.013\end{array}$ & $\begin{array}{c}0.140 \pm \\
0.012\end{array}$ & $\begin{array}{c}0.138 \pm \\
0.012\end{array}$ \\
\hline $\begin{array}{l}\text { H5, H6 } \\
\& \text { H7 }\end{array}$ & 3 & $\begin{array}{l}3.50 \pm \\
1.00 \mathrm{~b}\end{array}$ & $\begin{array}{c}15.60 \pm \\
1.92\end{array}$ & $\begin{array}{c}27.40 \pm \\
2.66\end{array}$ & $\begin{array}{c}0.134 \pm \\
0.011\end{array}$ & $\begin{array}{c}0.131 \pm \\
0.010\end{array}$ & $\begin{array}{c}0.132 \pm \\
0.009\end{array}$ \\
\hline
\end{tabular}

*The means with different letters within the same column differ significantly $(P<0.05)$.

The present results disagree with AlKhuzai (2018) in his study on Awassi sheep and Sadeghi et al. (2014) in their study on two breeds of the Iranian sheep indicated there was a significant effect of polymorphism of the POU1F1 gene on weaning weight., while Zhang et al. (2013), Pan et al. (2008) and Carrijo et al. 
(2008) found no significant effect for the polymorphism of POU1F1 gene on birth weight in cattle.

The results did not show any significant effect of the haplotypes of the POU1F1 gene on weights at weaning and six months of age. The haplotypes of $\mathrm{H} 1, \mathrm{H} 2, \mathrm{H} 3, \mathrm{H} 4$ and other were 15.67, 15.48, 15.84, 15.93 and $15.60 \mathrm{~kg}$ and 27.31, 27.14, 28.16, 29.27 and 27.40 and $\mathrm{kg}$ at weights of weaning and six months of age, respectively.

The results agreed with Sadeghi, et al. (2014) who found no significant effect on the polymorphism of the POU1F1 gene on lamb weight at weaning for two Iranian sheep breeds). Al-Khuzai (2018) showed a significant effect on the POU1F1 gene on weaning weight. A study on Korean cattle showed a significant effect of the polymorphism of the POU1F1 gene (exon 2) on calves weight at six months of age (Seong, et al., 2011). The results of table (3) showed no significant differences among the haplotypes of the POU1F1 gene on the daily weight gains. The daily weight gains from birth to six months of age were $0.131,0.130,0.133,0.138$ and $0.132 \mathrm{~kg}$ for haplotypes $\mathrm{H} 1, \mathrm{H} 2, \mathrm{H} 3, \mathrm{H} 4$ and other. The results disagree with those of Al-Khuzai (2018) on Awassi sheep and Ansary et al. (2008) on Iranian sheep who observed significant effect of polymorphism of the POU1F1 gene on daily weight gains of lambs.

Several studies such as Carrijo et al. (2008) in Brazilian cattle, Pan et al. (2008) in Chinese cattle and Stasio et al. (2002) did not observed any effect for the POU1F1 gene on body weights and daily weight gains.

Table (4): Effect haplotypes of POU1F1 gene on milk production and lactation period \pm standard deviation.

\begin{tabular}{|c|c|c|c|c|c|c|c|}
\hline Haplotypes & $\begin{array}{l}\text { Number } \\
\text { of Dams }\end{array}$ & $\begin{array}{c}\text { Daily milk } \\
\text { yield (kg) }\end{array}$ & $\begin{array}{c}\text { First } \\
\text { month } \\
\text { yield } \\
(\mathbf{k g})\end{array}$ & $\begin{array}{c}\text { Second } \\
\text { month } \\
\text { yield } \\
(\mathbf{k g})\end{array}$ & $\begin{array}{l}\text { Third } \\
\text { month } \\
\text { yield } \\
(\mathbf{k g})\end{array}$ & $\begin{array}{c}\text { Total } \\
\text { milk yield } \\
(\mathrm{kg})\end{array}$ & $\begin{array}{c}\text { Lactation } \\
\text { period } \\
(\text { day })\end{array}$ \\
\hline H1 & 22 & $\begin{array}{c}0.813 \pm \\
0.114\end{array}$ & $\begin{array}{c}28.86 \pm \\
3.38\end{array}$ & $\begin{array}{c}33.05 \pm \\
7.76\end{array}$ & $\begin{array}{c}19.86 \pm \\
3.57\end{array}$ & $\begin{array}{c}88.13 \pm \\
14.75\end{array}$ & $\begin{array}{c}108.00 \pm \\
4.19\end{array}$ \\
\hline $\mathrm{H} 2$ & 13 & $\begin{array}{c}0.801 \pm \\
0.127\end{array}$ & $\begin{array}{c}27.97 \pm \\
4.39\end{array}$ & $\begin{array}{c}33.41 \pm \\
8.27\end{array}$ & $\begin{array}{c}19.64 \pm \\
2.81\end{array}$ & $\begin{array}{c}85.52 \pm \\
15.20\end{array}$ & $\begin{array}{c}106.46 \pm \\
3.04\end{array}$ \\
\hline H3 & 5 & $\begin{array}{c}0.810 \pm \\
0.098\end{array}$ & $\begin{array}{c}28.68 \pm \\
2.72\end{array}$ & $\begin{array}{c}32.26 \pm \\
9.22\end{array}$ & $\begin{array}{c}20.46 \pm \\
0.44\end{array}$ & $\begin{array}{c}87.14 \pm \\
11.86\end{array}$ & $\begin{array}{c}107.40 \pm \\
1.81\end{array}$ \\
\hline $\mathrm{H} 4$ & 3 & $\begin{array}{c}0.852 \pm \\
0.062\end{array}$ & $\begin{array}{c}30.40 \pm \\
1.73\end{array}$ & $\begin{array}{c}36.75 \pm \\
6.14\end{array}$ & $\begin{array}{c}16.90 \pm \\
0.34\end{array}$ & $\begin{array}{c}93.08 \pm \\
6.25\end{array}$ & $\begin{array}{c}109.33 \pm \\
1.15\end{array}$ \\
\hline $\begin{array}{c}\text { H5, H6 \& } \\
\text { H7 }\end{array}$ & 3 & $\begin{array}{c}0.773 \pm \\
0.155\end{array}$ & $\begin{array}{c}26.63 \pm \\
4.15\end{array}$ & $\begin{array}{c}32.23 \pm \\
8.45\end{array}$ & $\begin{array}{c}18.58 \pm \\
3.06\end{array}$ & $\begin{array}{c}81.77 \pm \\
16.13\end{array}$ & $\begin{array}{c}105.67 \pm \\
2.06\end{array}$ \\
\hline
\end{tabular}




\section{Effect of haplotypes of the POU1F1 gene on milk production and lactation period.}

Daily milk production was not affected by the haplotypes of the POU1F1 gene (0.813, $0.801,0.810,0.852$ and $0.773 \mathrm{~kg}$ ) for haplotypes $\mathrm{H} 1, \mathrm{H} 2, \mathrm{H} 3, \mathrm{H} 4$ and other respectively (table 4). The results did not show any significant differences in monthly and total milk production among the different haplotypes. The total milk production of the haplotypes $\mathrm{H} 1, \mathrm{H} 2, \mathrm{H} 3, \mathrm{H} 4$, and others were $88.13,85.52,87.14,93.08$ and $81.77 \mathrm{~kg}$, respectively.

In term of the lactation period, the results also showed the absence of a significant effect for haplotypes of the POUIF1 gene which recorded 108.00, 106.46, 107.40, 109.33 and 105.67 days for the haplotypes H1, H2, H3, $\mathrm{H} 4$ and other, respectively. The results of this study agreed with Al-Khuzai (2018) who found no significant effect of the polymorphism of the POU1F1 gene on milk production for the Iraqi Awassi sheep. The absence of the significant effect of the haplotypes of the POU1F1 gene on all of

daily, monthly and total milk production may due to the fact that the change in the nitrogen bases in the POU1F1 gene did not alter any of the amino acids for $P O U 1 F 1$ protein, or due to the need for more animals to ascertain the true effect of the gene. The results of the current study were agreed with Mura et al. (2012), who found no effect of the POU1F1 gene on the amount of milk produced from Sarda sheep in Poland, Daga et al. (2013), showed nosignificant differences between different haplotypes for POU1F1 gene in milk production and its chemical components fat and protein in Sarda goats in Italy.
Ozmen et al. (2014) showed significant differences in the polymorphism of the POU1F1 gene in the milk production in sheep, there were also significant differences in the chemical components of the milk (fat, protein, and lactose). While Huang, et al. (2008) and Chauhan, et al. (2015) found there was a significant effect of the milk production between the polymorphisms of the POU1F1 gene in cattle.

The presence or absence of the POU1F1 gene polymorphisms effect in the current study compared to other different studies may belong to the differences in the studied breeds, technique, the studied fragment (exons or introns) from the gene, methods of statistical analysis and the numbers of animals used.

\section{Effect of haplotypes of POU1F1 gene on chemical milk components.}

Table (5) showed no significant effect of the haplotypes of the POU1F1 gene on chemical milk components (fat, protein, and lactose) during the different months of milk production. The results of the current study agreed with Mura et al. (2012) who found no significant effect of polymorphism for the POU1F1 gene in milk chemical components (fat, protein, and lactose) in Sarda sheep. The results were also agreed with Al- Khuzai, (2018), who showed no significant effect of the different polymorphisms of the POUIF1 gene on milk chemical components (fat, milk, and lactose). In similar studies on the POU1F1 gene in Turkish cattle, Aytekin and Boztepe (2013) found no significant effect of the different polymorphisms of the POU1F1 gene on milk chemical components. While Ozmen et al. (2014) obtained three breeds of Turkish sheep effectively on the 
polymorphisms for POU1F1 gene on fat and lactose ratio in milk. Other similar studies on goats indicated a significant effect on the polymorphisms of the POUIF1 gene in milk chemical components (fat, protein, and lactose).

Table (5): Effect of haplotypes of the POU1F1 gene on milk components (fat, protein, lactose) \pm standard deviation.

\begin{tabular}{llllllllll}
\hline \multirow{2}{*}{$\begin{array}{l}\text { Haplotype } \\
\text { s }\end{array}$} & \multicolumn{3}{c}{ First month } & \multicolumn{3}{c}{ Second month } & \multicolumn{3}{c}{ Third month } \\
\cline { 2 - 11 } & $\begin{array}{c}\text { Lactose } \\
(\%)\end{array}$ & $\begin{array}{c}\text { Protein } \\
(\%)\end{array}$ & Fat (\%) & $\begin{array}{c}\text { Lactose } \\
(\%)\end{array}$ & $\begin{array}{l}\text { Protein } \\
(\%)\end{array}$ & Fat $(\%)$ & $\begin{array}{c}\text { Lactose } \\
(\%)\end{array}$ & $\begin{array}{c}\text { Protein } \\
(\%)\end{array}$ & Fat (\%) \\
\hline H1 & $5.01 \pm$ & $3.95 \pm$ & $5.32 \pm$ & $5.14 \pm$ & $4.07 \pm$ & $5.52 \pm$ & $5.20 \pm$ & $4.04 \pm$ & $5.18 \pm$ \\
& 0.02 & 0.16 & 0.57 & 0.23 & 0.19 & 0.76 & 0.18 & 0.12 & 0.79 \\
\hline H2 & $5.10 \pm$ & $4.01 \pm$ & $5.70 \pm$ & $5.27 \pm$ & $4.08 \pm$ & $5.92 \pm$ & $5.29 \pm$ & $4.02 \pm$ & $5.62 \pm$ \\
& 0.33 & 0.22 & 0.55 & 0.34 & 0.20 & 0.77 & 0.28 & 0.2 & 0.78 \\
\hline H3 & $5.07 \pm$ & $4.05 \pm$ & $5.59 \pm$ & $4.98 \pm$ & $3.89 \pm$ & $5.69 \pm$ & $5.10 \pm$ & $4.02 \pm$ & $5.41 \pm$ \\
& 0.06 & 0.12 & 0.84 & 0.16 & 0.13 & 0.97 & 0.31 & 0.18 & 0.93 \\
\hline H4 & $4.99 \pm$ & $4.00 \pm$ & $5.32 \pm$ & $5.23 \pm$ & $4.04 \pm$ & $5.05 \pm$ & $5.23 \pm$ & $4.01 \pm$ & $5.17 \pm$ \\
& 0.15 & 0.05 & 0.80 & 0.17 & 0.13 & 0.96 & 0.05 & 0.06 & 1.13 \\
\hline H5, H6 \& & $5.04 \pm$ & $3.85 \pm$ & $5.18 \pm$ & $5.20 \pm$ & $4.03 \pm$ & $5.50 \pm$ & $5.21 \pm$ & $4.12 \pm$ & $5.48 \pm$ \\
H7 & 0.20 & 0.23 & 0.80 & 0.21 & 0.14 & 0.75 & 0.27 & 0.69 & 0.98 \\
\hline
\end{tabular}

Table (6): The fragments' sequences submitted to Gene Bank (NCBI).

\begin{tabular}{cccl}
\hline Fragments & $\begin{array}{c}\text { Gene } \\
\text { Name }\end{array}$ & \multicolumn{1}{c}{ Local on the gene } & \multicolumn{1}{c}{ Accession Numbers } \\
\hline P1 & POU1F1 & Exon-1 \& part of Intron-1 & LC469344, LC480423, LC480424 \\
\hline P2 & POU1F1 & Exon-2 \& part of Intron-2 & LC469345, LC480425, LC480426 \\
\hline P3 & POU1F1 & part of Intron2 \& Exon-3 & $\begin{array}{l}\text { LC469346, LC480427, LC480428, } \\
\text { LC480429, LC480430 }\end{array}$ \\
\hline P4 & POU1F1 & Exon-4 \& part of Intron-4 & $\begin{array}{l}\text { LC469347, LC480431, LC480432, } \\
\text { LC480433, LC480434 }\end{array}$ \\
\hline P5 & POU1F1 & part of Intron-4 \& Exon-5 & LC469348, LC480435, LC480436 \\
\hline P6 & POU1F1 & Exon-6 \& part of UTR,3 & LC469349 \\
\hline
\end{tabular}




\section{Conclusions}

Many of the changes in nitrogen bases found in different sites of POU1F1 gene there had no association with haplotypes and most of the production traits, such as weights and daily weight gains, with an exception to birth weight, which found the effect of some haplotypes. The results did not show any effect of haplotypes of POU1F1 gene on milk production, the fragments of the POU1F1 gene in this study of Awassi sheep breed had been submitted at Gene Bank for the first time in Iraq under the independent accession numbers

\section{Acknowledgement}

The authors acknowledge the support of Department of Animal Production, College of Agriculture, University of Basrah for conducting the research work.

\section{Conflicts of interest}

The authors declare that they have no conflict of interests.

Ethical approval: all applicable national and international guidelines for the care and use of animals were followed.

\section{References}

Al-Khuzai, H.M. (2018). Detection of IGFBP-3, POUIFI and BMP15 genes and their association with the productive and reproductive performance for Awassi sheep. Ph. D. Thesis. Coll. Agric., Univ. Baghdad: 165pp.

Ansary, M.; Tahmoorespour, M.; Nassiry,R. \& Javadmanesh, A. (2008). Study the PIT1 gene polymorphism and association to average daily gain in Iranian Baluchi sheep. 10 ${ }^{\text {th }}$ World Congress on Anim. Prod. South Africa, 25: 23-28.

Aytekin, I. \& Boztepe, S. (2013). Association of PIT-1 Gene polymorphism with milk yield and composition traits in brown Swiss cattle. J. Anim. Plant Sci., 23: 12811289.

Bastos, E.; Avila, S. Cravador, A.; Renaville, R.; Pinto, H.G. \& Castrillo, J.L. (2006). Identification and characterization of four splicing variants of ovine POU1F1 gene. Gene., 382: 12-19.

Carrijo, S.M.; De Alencar, M.M.; Toral, F.L.B. \& Reagitano, L.C., (2008) Association of PITl genotypes with growth traits in Canchim cattle. Sci. Agric. ., 65: 116-121.

Chauhan, A.; Tiwari, A.; Singh, S.P.; Sharma, D.; Kumar, S.; Goel, R.; Bhattachrya, A. \& Singh, V. (2015). Association of PIT-1 gene polymorphism with milk production traits in Sahiwal cattle. Indian J. Anim. Sci., 85: 610-612.

Daga, C.; Paludo, M.; Luridiana, S.; Mura, M.C.; Bodano, S.; Pazzola, M.; Dettori, M.L.; Vacca, G.M. \& Carcangiu, V. (2013). Identification of novel SNPs in the Sarda breed goats POU1F1 gene and their association with milk productive performance. Mol. Biol. Rep., 40: 28292835 .

Gil-Puig, C.; Blanco, M.; García-Caballero, T.; Segura, C. \& Fernández, R.P. (2002). Pit-1/GHF-1 and GH expression in the MCF-7 
human breast adenocarcinoma cell line. J. Endocr., 173: 161-167.

Huang, W.; Maltecca, C. \& Khatib, H.A. (2008). Proline-to-histidine mutation in POU1F1 is associated with production traits in dairy cattle Anim. Genet., 39: 554557.

Mura, M.C.; Daga, C.; Paludo, S.L.; Pazzola, M.; Bodano, S.; Dettori, M.L.; Vacca, G.M. \& Carcangiu, V. (2012). Analysis of polymorphism within POU1F1 gene in relation to milk production traits in dairy Sarda sheep breed. Mol. Biol. Rep., 39: 6975-6979.

Ozmen, O.; Kul, S. \& Unal, E.O. (2014). Polymorphism of sheep POU1F1 gene exon 6 and 3'UTR region and their association with milk production traits. Iranian J. Vet. Res., 15: 331-335.

Pan, C.Y.; Lan, Chen, H.; Yang, D.Y.; Hua, L.S.; Yang, X.B.; Lei, C.Z.; Gui, Y.K.; Zhang, B.; Zhang, C.L.; Kang, X.T. \& Wang, I.Q. (2008). A DdeI PCR-RFLP detecting a novel missense mutation of the POU1F1 gene showed no effects on growth traits in cattle. Czech J. Anim. Sci., 12: 523-527.

Sadeghi, M.I.; Jalil-Sarghale, A. \& MoradiShahrbabak, M. (2014). Associations of POU1F1 gene polymorphisms and protein structure changes with growth traits and blood metabolites in two Iranian sheep breeds. J. Genet., 93: 831-835.

Seong, J.; Oh, J.D.; Cheong, I.C.; Lee, K.W.; Lee, H.K.; Suh, D.S.; Jeon, G.J.; Park,
K.D. \& Kong, H.S. (2011). Association between polymorphisms of Myf5 and POU1F1 genes with growth and carcass traits in Hanwoo (Korean cattle). Genes \& Genomics, 33: 425-430.

Stasio, L.D.; Sartore, S. \& Alberta, A. (2002). Lack of association of GHI and POUIF1 gene variants with meat production traits in Piedmontese cattle. Anim. Genet., 33: 6164.

SPSS, (2013). Statistical Package of Social Science .Ver. 22. Application Guide .Copy right by Spss Inc.

Sun, H.S.; Anderson, L.L.; Yu, T.P.; Kim, K.S.; Klindt, J. \& Tuggle, C.K. (2002). Neonatal Meishan pigs show POU1F1 genotype effects on plasma GH and PRL concentration. Anim. Reprod. Sci., 69: 223-237.

Woollard, J.; Tuggle, C.K. \& Leon, FA. (2000). Localization of POU1F1 to bovine, ovine, and caprine 1q21-22. J. Anim. Sci., 78: 242-243.

Zhang, C.; Liu, B.; Chen, H.; Lan, C.; Zhang, Z.; Zhang, R. \& Shaaxi, P.R. (2013). Associations of a HinfI PCR-RFLP of POU1F1 Gene with Growth Traits in Qinchuan Cattle. Anim. Biot., 20: 71-74.

Zhu, H.; Zhang, Y.; Bai, Y.; Yang, H.; Yan, H.; Liu, J.; Shi, L.; Song, X.; Li, L.; Dong, S.; Pan, C.; Lan, X. \& Qu, L. (2019). Relationship between SNPs of POU1F1 Gene and litter size and growth traits in shaanbei white cashmere goats. Anim., 9: 114. doi:10.3390/ani9030114. 